\title{
POLLEN GRAIN MORPHOLOGICAL CHARACTERISTICS OF AMERICAN PERSIMMON (DIOSPYROS VIRGINIANA L.)
}

\author{
Grygorieva Olga ${ }^{1 *}$, Motuleva Svetlana ${ }^{2}$, Nikolaieva Nataliia ${ }^{3}$, \\ Klymenko Svitlana', Schubertová Zuzana ${ }^{3}$, Brindza Jan ${ }^{3}$
}

\author{
${ }^{1}$ M.M. Gryshko National Botanical Garden of Ukraine of National Academy of Sciences, Kyiv, Ukraine \\ ${ }^{2}$ Federal State Budgetary Scientific Institution All-Russian Horticultural Institute for Breeding, \\ Agrotechnology and Nursery, Moscow, Russia \\ ${ }^{3}$ Faculty of Agrobiology and Food Resourses, Slovak University of Agriculture in Nitra, Slovak Republic
}

Morphology of pollen grain was described for nine American persimmons (Diospyros virginiana L.) genotypes (DV-01 - DV-09) at the Institute of Biodiversity and Biological Safety of Slovak Agricultural University in Nitra using an electron microscope Carl Zeiss LS 15, and the microphotographs were taken. The measurement of morphometric parameters was carried out on 50 pollen grains from each genotype using the AxioVision Rel. 4.8.2.0 program. The measurements were made in micrometer $(\mu \mathrm{m})$. The length of polar axis $(P)$ and the equatorial diameter $(E)$ of grain, $P / E$ ratio were measured and their variation was compared among studied genotypes. The polar axis and equatorial diameter of pollen grains values were varied from 51.94 to $78.60 \mu \mathrm{m}$ and from $23.00 \mu \mathrm{m}$ to $42.71 \mu \mathrm{m}$, respectively. This study showed that there were significant differences among the genotypes in all measured factors. Pollen grains are radialsymmetrical, isopolar, tricolpate (with three sulcus). Exine surface is a bicomponent sculptural type with small perforate-undulate or wrinkled weakly perforate. Percentages of abnormal pollen grains ranged from 2.0 to $19.3 \%$ among the genotypes. It was noted that diversity of surface sculpturing of pollen grains in combination with shape and sizes of them enables to use complex of thin morphologic signs for Diospyros virginiana pollen identification.

Keywords: American persimmon; genotypes; pollen; SEM; morphology

\section{Introduction}

The American persimmon (Diospyros virginiana L.) is of great practical interest for fruit growing. In addition, the Diospyros virginiana is a valuable decorative and medicinal plant. For the last years was derived good cultivars of Diospyros virginiana and some of them are superior the best cultivars of Diospyros kaki (Spongberg, 1979; Grygorieva et al., 2011). Today more than 200 cultivars of Diospyros virginiana exist and their fruits have differences in fruits shape, size, color and ripening (Hague, 1911; Spongberg, 1979; Goodell, 1982; Zohary, 2004).

The investigations of the morphological peculiarities of pollen grains from specific genotypes and cultivars are important and useful for taxonomy, phylogeny, palaeobotany, breeding programmes, e.g., pear (Westwood and Challice, 1978), grape (Ahmedullah, 1983), sweet cherry (Miaja et al., 2000), apricot (Arzani et al., 2005), cornelian cherry (Mert, C. 2009), persimmon (Grygorieva et al., 2011),

\footnotetext{
*Corresponding author: Olga Grygorieva, M.M. Gryshko National Botanical Garden of Ukraine of National
} Academy of Sciences, Kyiv, Ukraine, $₫$ olgrygorieva@gmail.com 
hazelnut (Nikolaieva et al., 2014), jujube (Rouhakhsh, et al., 2014), and chestnut (Grygorieva et al., 2015).

Shape, size, surface morphology, and ultrastructure of pollen grains are of great importance in the characterization of the pollen grains (Fogle, 1977; Martens and Fretz, 1980; Jiang et al., 2004; Grygorieva et al., 1010; Brindza and Brovarskyi, 2013; Dyakova, 2014).

The morphology of common persimmon pollen was not investigated under conditions of Ukraine. The knowledge of pollen morphological characteristics can be an adequate method for identification and the newly-developed genotypes of Diospyros virginiana.

\section{Materials and methodology}

Locating trees and data collection. The pollen of 9 Diospyros virginiana genotypes (DV-01 DV-09) from the collection of M.M. Gryshko National Botanical Garden of NAS of Ukraine (NBG) was investigated.

Pollen grains collection. Freshly flowers (not opened) were collected randomly from the different genotypes at the balloon stage (June 2015). Pollen samples released from dry male flowers were further dried under laboratory conditions. The dry pollen was used for a microscopic study of morphological characteristics. The samples of pollen grains were applied to double-tape, fastened to metal object tables with $10 \mathrm{~mm}$ diameter.

Scanning electron microscopy (SEM). The pollen grains were studied at the Institute of Biodiversity and Biological Safety of Slovak Agricultural University in Nitra using an electron microscope Carl Zeiss LS 15, and the microphotographs were taken.

Typical exine patterns, shape, size and the dimensions of pollen grains for each Diospyros virginiana genotypes were determined by using a scanning electron micrograph (SEM).

Morphometric characteristics. The measurement of morphometric parameters was carried out on 50 pollen grains from each genotype using the AxioVision Rel. 4.8.2.0 program. The measurements were made in micrometers $(\mu \mathrm{m})$. The characterization of pollen grains was calculated by taking the following parameters: the polar axis (P-line connecting the proximal and distal pole), the equatorial axis (E-a line perpendicular to the polar axis and located in the equatorial plane).

Statistical analysis. Basic statistical analyses were performed using SAS System v. 9.2 (SAS 2009). The DISTRIBUTION analysis (verification of normal distribution of input data), the CLUSTER procedure, the TREE procedure (creating the dendrogram) in SAS 9.2. for further detailed analysis were used. Differences among means were determined for significance at $P<0.05$ using Tukey's test. Variability of all these parameters was evaluated using descriptive statistics. Dendrogram clustering the data from the individual experimental genotypes using average linkage using Euclidian distance as a metric.

\section{Results and discussion}

It is known, the Diospyros virginiana flowers are prevailingly unisexual, only exceptionally being bisexual. It means the plant bears both, the male and female flowers. Sometimes the dioecism occurs. Many individuals have only female flowers and the fruits can arise without fertilization - by parthenocarpy and they are seedless. Information on Diospyros virginiana pollen grain traits occurs scarcely in a few papers (Erdtman 1966; Geeraerts et al., 2009; Grygorieva et al., 2010). 

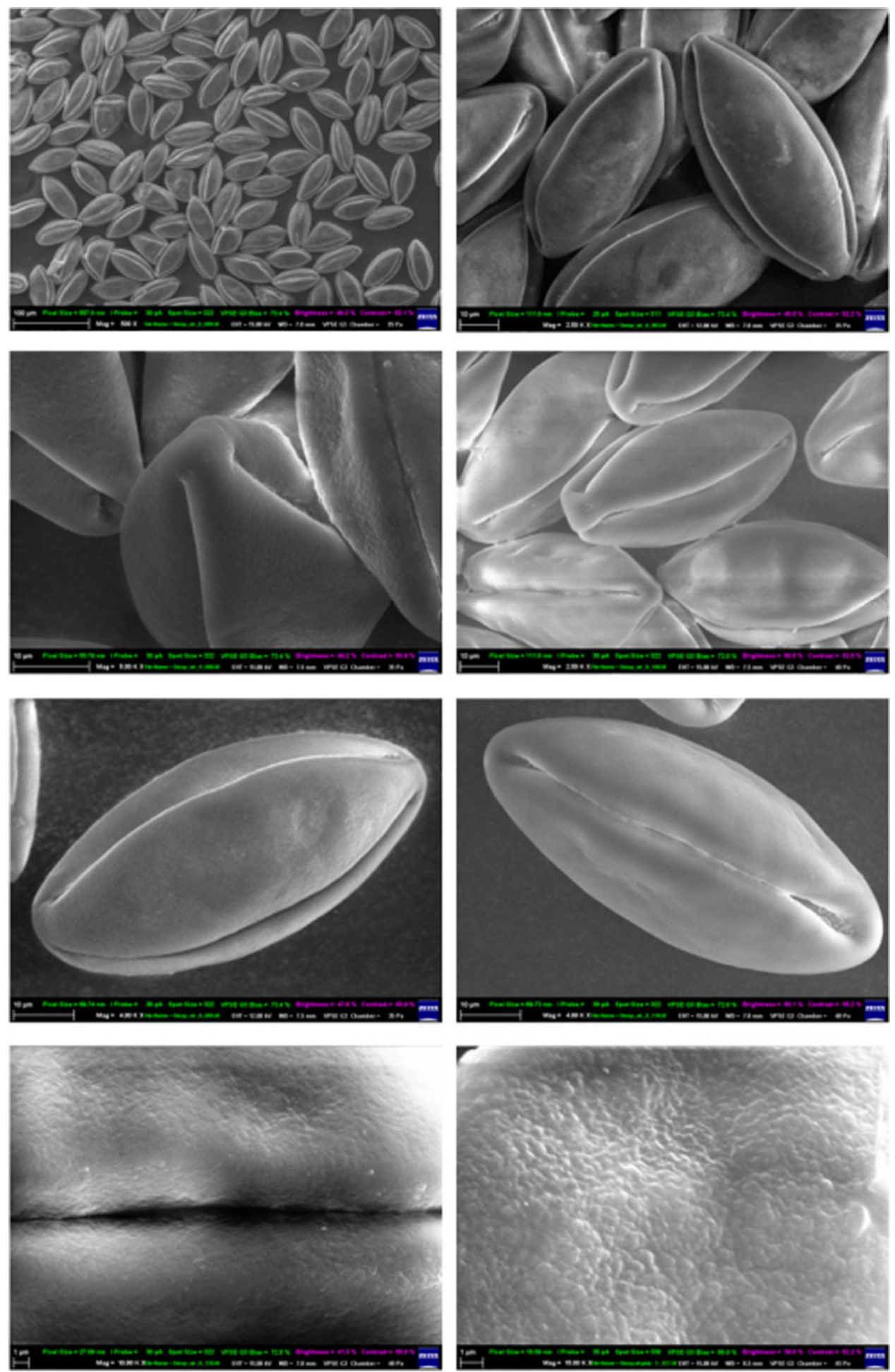

Figure 1

Pollen grains of Diospyros virginiana L. species in different positions

Photo: Motyleva, 2015 
Pollen grains of the Diospyros virginiana occur individually - solitary, defined as monads. This study on pollen morphology of tested Diospyros virginiana showed that pollen grains are radially symmetrical, isopolar and according to the localization of apertures are zono-tricolpate. Three compound apertures are according to distribution equidistant. The size, shape of pollen grains and number of apertures are documented on Figure 1.

Pollen grains possess three prolonged apertures - colpi which are narrowed at poles. An additional pole is in the colpus middle at the equatorial centre (circular equatorial aperture). This classification correlates with literature data (Sowunmi 1995; Kodela 2006; Geeraerts et al., 2009).

The exine membrane in an area of the colpus is granulated. From the cytological view the pollen grains of Diospyros virginiana are bicellular (Сравнительная эмбриология..., 1983). It means that generative cell division on sperm cells is accomplished in the pollen pocket. Our studies using REM have shown that the exine of tested species is not smooth but sculptured. There are dominating finely striation (striate), scarring (scabrate) or wrinkles, also with the occurrence of perforations.

An important morphological characteristic is the size of pollen grains. The length of polar axis $(P)$ measured in the mentioned of the Diospyros virginiana (Table 1, Figure 2) varied from 51.94 to $78.60 \mu \mathrm{m}$ and the width of the equatorial axis $(E)$ was in a range of $23.00-42.71 \mu \mathrm{m}$. For example Erdtman (1952) in Diospyros virginiana reported the mean value for polar axis length $(P) 59.0 \mu \mathrm{m}$ and the equatorial axis $(E) 46.0 \mu \mathrm{m}$ whereas Geeraerts et al. (2009) for the same species found the mean values for the length $P-41.4 \mu \mathrm{m}$ and $\underline{E}-31.2 \mu \mathrm{m}$ (Table 2 ).

Table 1 The measured pollen morphological traits of selected genotypes of Diospyros virginiana $\mathrm{L}$.

\begin{tabular}{|l|c|c|c|c|c|c|c|c|c|c|}
\hline \multirow{2}{*}{ Genotypes } & min & \multicolumn{2}{|c|}{$\max$} & $\mathbf{C V} \%$ & $\min$ & $\max$ & $\mathbf{C V} \%$ & $\min$ & $\max$ & $\mathbf{C V} \%$ \\
\cline { 2 - 10 } & \multicolumn{2}{|c}{$\boldsymbol{P}$ - polar axis $(\boldsymbol{\mu m})$} & \multicolumn{2}{c|}{$E$ - equatorial axis $(\boldsymbol{\mu m})$} & \multicolumn{2}{c|}{ SI - shape index (P/E) } \\
\hline DV-01 & 51.94 & 70.50 & 5.91 & 23.99 & 30.44 & 5.21 & 1.79 & 2.81 & 8.46 \\
\hline DV-02 & 64.15 & 78.44 & 4.24 & 30.22 & 37.98 & 6.43 & 1.79 & 2.39 & 7.70 \\
\hline DV-03 & 61.23 & 77.09 & 4.56 & 23.00 & 38.97 & 11.09 & 1.67 & 2.91 & 11.39 \\
\hline DV-04 & 62.44 & 75.92 & 3.50 & 25.63 & 38.29 & 7.85 & 1.84 & 2.62 & 7.89 \\
\hline DV-05 & 67.75 & 78.14 & 4.23 & 30.06 & 38.36 & 5.21 & 1.84 & 2.50 & 7.52 \\
\hline DV-06 & 63.32 & 76.13 & 4.22 & 26.09 & 35.53 & 6.80 & 2.00 & 2.68 & 7.43 \\
\hline DV-07 & 61.70 & 77.45 & 4.79 & 27.11 & 42.71 & 9.35 & 1.47 & 2.57 & 10.43 \\
\hline DV-08 & 63.18 & 78.60 & 4.90 & 29.11 & 42.45 & 6.90 & 1.65 & 2.54 & 8.86 \\
\hline DV-09 & 60.08 & 75.48 & 4.94 & 28.46 & 36.54 & 6.35 & 1.82 & 2.46 & 7.40 \\
\hline
\end{tabular}

min - minimum value; max - maximum value; CV - variation coefficient (\%)

The values of variation coefficient were in the range of $3.50-5.91 \%$ for polar and in the range of $5.21-11.09 \%$ for equatorial axes.

The genetic relationship among the 9 genotypes of Diospyros virginiana (Figure 3) was examined by cluster analysis. Dendrogram has shown 3 main group in cluster A, cluster B and cluster $C$. Four of 9 genotypes were included in cluster group $B$ and cluster group $C$, respectively. And one genotype formed cluster group $A$. The groups $B$ and $C$ had highest means for pollen morphometric characteristics. 


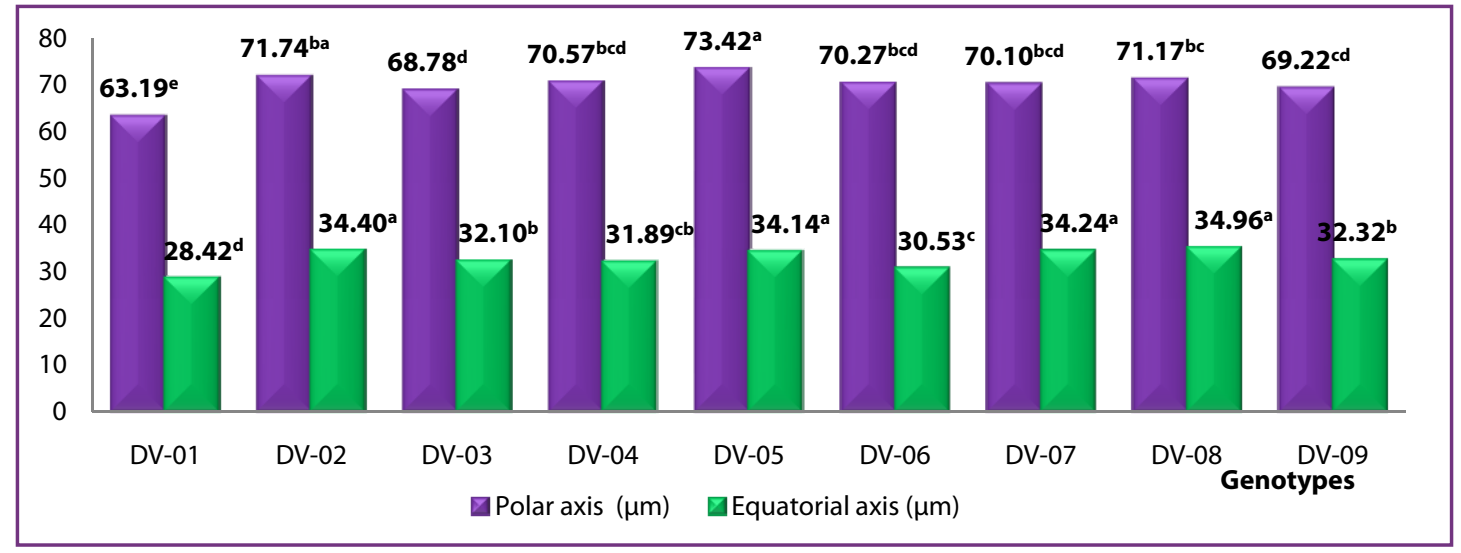

Figure 2 The average values of polar and equatorial axes of Diospyros virginiana L. pollen of selected genotypes (Means in each column followed by different letters are not significantly different $(P \leq 0.05)$

\section{Genotypes}

DV-01

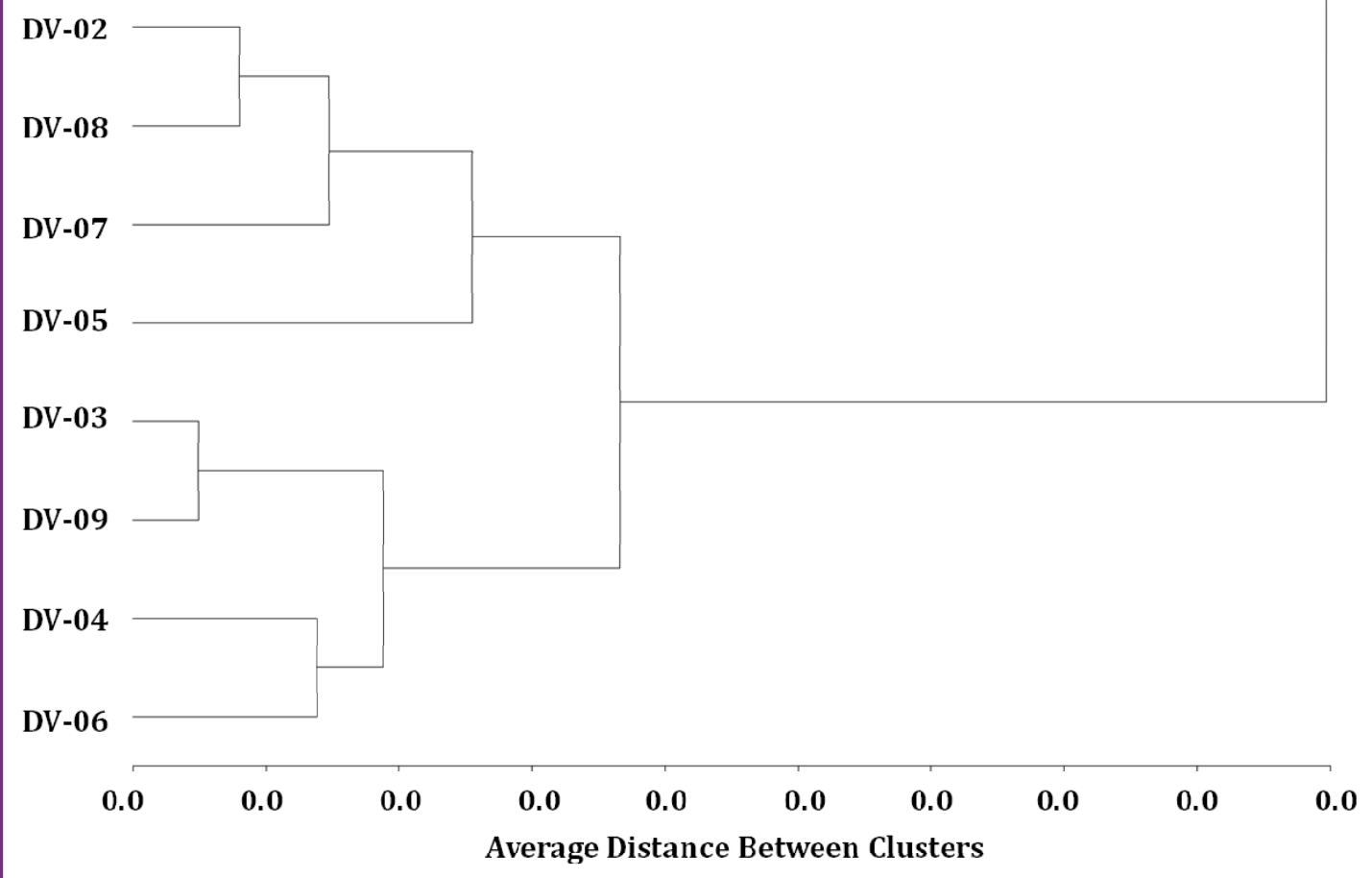

Figure 3 Dendrogram of Diospyros virginiana L. 9 genotypes based on morphometric characteristics of pollen 
Shape index $(S I)$ of pollen grain depends on parameters of polar $(P)$ and equatorial $(E)$ axis. Shape index (the $P / E$ ratio) of tested species varied from 1.47 to 2.91 (Table 2, Figure 4).

Table 2 Literature data on pollen morphological traits in the Diospyros virginiana L.

\begin{tabular}{|l|c|c|}
\hline Characteristic & Value & Autors \\
\hline \multirow{3}{*}{ Polar axis, $\boldsymbol{\mu m}$} & 41.4 & Geeraerts et al., 2009 \\
\cline { 2 - 3 } & 59.0 & Erdtman, 1952 \\
\cline { 2 - 3 } & $51.39(49.28-55.41)$ & Grygorieva, 2010 \\
\hline \multirow{3}{*}{ Equatorial axis, $\mathbf{\mu m}$} & 31.2 & Geeraerts et al., 2009 \\
\cline { 2 - 3 } & 46.0 & Erdtman, 1952 \\
\cline { 2 - 3 } & $23.56(21.40-25.94)$ & Grygorieva, 2010 \\
\hline \multirow{2}{*}{ SI - shape index } & 1.32 & Geeraerts et al., 2009 \\
\cline { 2 - 3 } & 2.18 & Grygorieva, 2010 \\
\hline
\end{tabular}

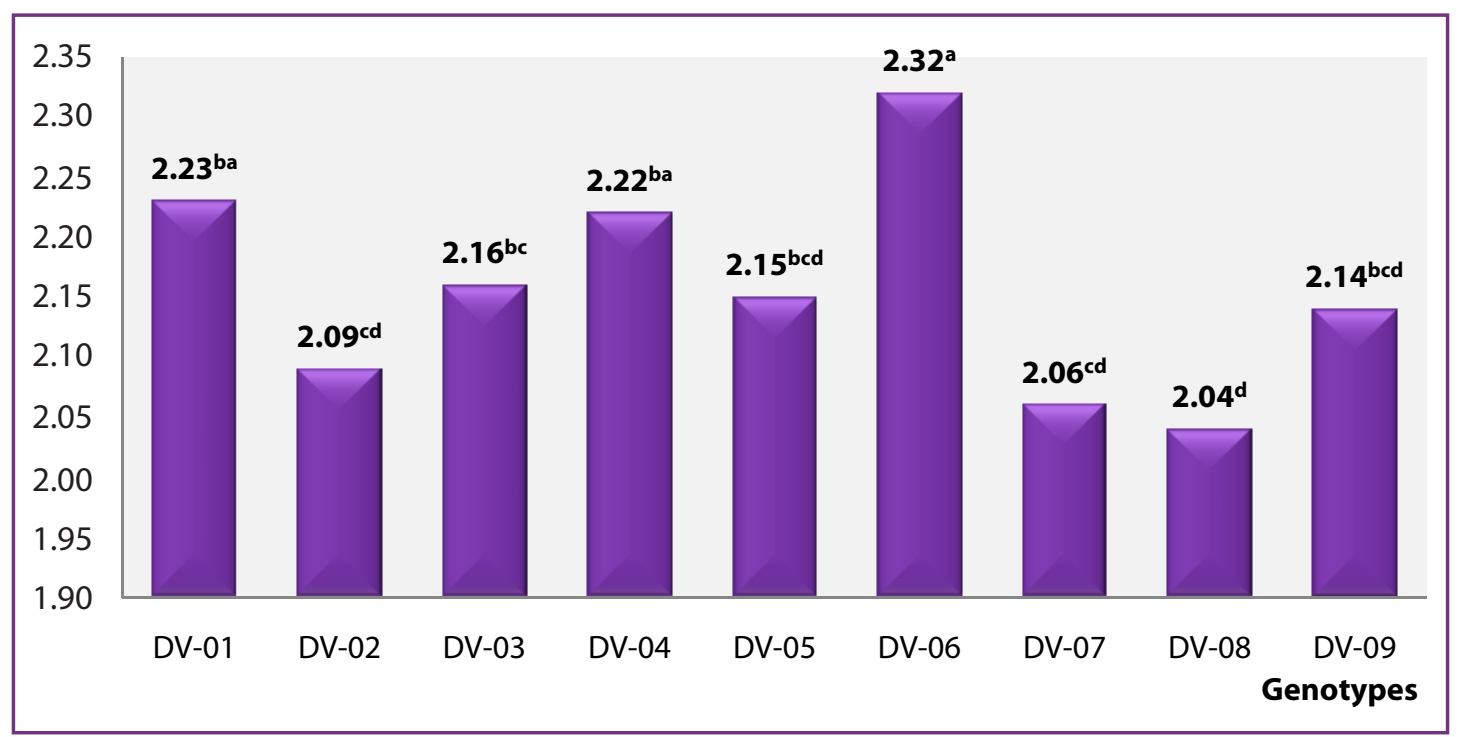

Figure 4 Mean values of pollen shape index of Diospyros virginiana $L$. of selected genotypes (Means in each column followed by different letters are not significantly different $(P \leq 0.05)$

Alongside normal pollen grains, each genotype examined also displayed a proportion of abnormally formed pollen grains. Percentages of abnormal pollen grains among the cultivars ranged from $2.0 \%$ to $19.3 \%$ (Figure 5). These values showed that there are no significant problems of pollen abnormality among the genotypes examined with the exception of DV-03. 


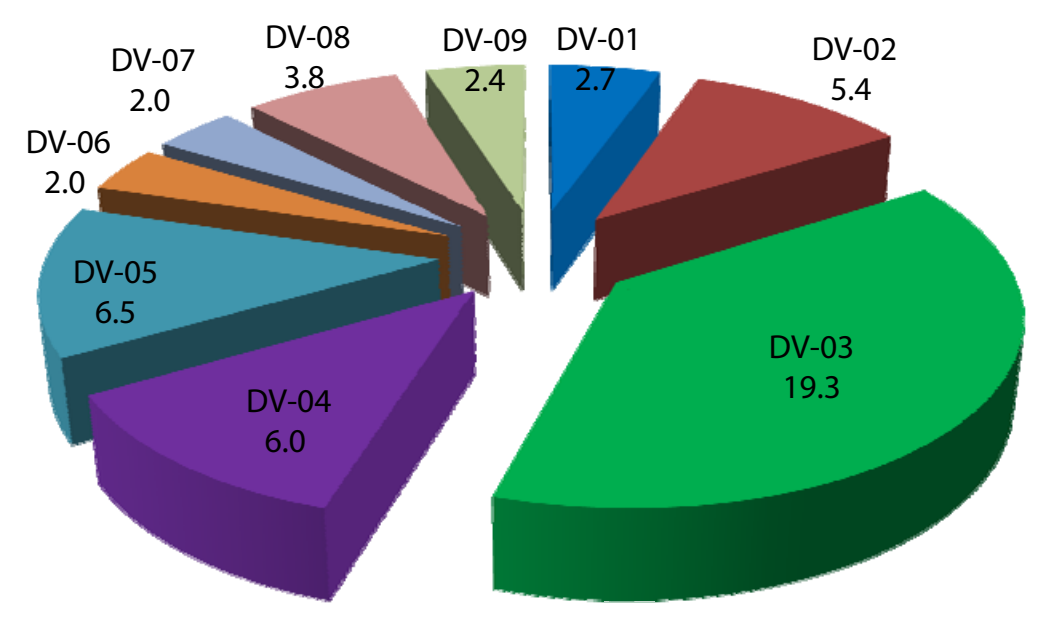

Figure 5 Abnormal pollen (\%) of Diospyros virginiana L. of selected genotypes

\section{Conclusions}

In the present work, morphologic and micro-sculptural characteristics of pollen grains of Diospyros virginiana (DV-01 - DV-09) 9 genotypes were carried out as a comparative study. Ascertained diversity of pollen grains shape and sizes in aggregate with sculptural features of exine surface enables to characterize pollen according to the complex of signs. Micro-sculptural features of exine surface may be regarded as markers signs and in the future use them for identification of Diospyros virginiana pollen.

\section{Acknowledgments}

The publication was prepared with the active participation of researchers in international network AGROBIONET, as a part of international program "Agricultural biodiversity to improve nutrition, health and quality of life" (TRIVE ITMS26110230085) within the project ITEBIO-ITMS 26220220115 and AgroBioTech -ITMS 26220220180.

\section{References}

Ahmedullah, M. 1983. Pollen morphology of selected Vitis cultivars. J. Amer. Soc. Hort. Sci., vol. 108, p. 155-160.

Arzani, K., Nejatian, M.A., Karimzadeh, G. 2005. Apricot (Prunus armeniaca) pollen morphological characterisation through scanning electron microscopy, using multivariate analysis. N. Z. J. Crop Hort. Sci., vol. 33, p. 381-388.

Brindza, J. Brovarskyi, V. 2013. Pollen and bee pollen of some plant species. Kyiv: Korsunskiy vidavnichiy dim «Vsesvit». 137 p.

Dyakova, I. 2014. Pollen morphology of the genus Malus Mill. Modern Phytomorphology, vol. 6, p. 129-132. https://doi.org/10.5281/zenodo.160613

Erdtman, G. 1966. Pollen morphology and plant taxonomy: Angiosperms. New York, NY : Hafner Publishing Company.

Fogle, H.W. 1977. Identification of tree fruit species by pollen ultrastructure. J. Amer. Soc. Hort. Sci., vol. 102, p. 548-551. 
Geeraerts, A., Raeymaekers, J. A.M., Vinckier, S., Pletser, A., Smets, E., Huysmans, S. 2009. Systematic palynology in Ebenaceae with focus on Ebenoideae: Morphological diversity and character evolution. Review of Paleobotany and Palynology, vol. 153, no. 3-4, p. 336-353.

Goodell, E. 1982. Promising fruit plants for northern landscapes. Arnoldia, vol. 40, p. 103-133. http:// arnoldia.arboretum.harvard.edu/pdf/articles/1982-42-4-two-promising-fruit-plants-for-northernlandscapes.pdf

Grygorieva, O., Brindza, J., Ostrolucká, M.G., Klymenko, S., Ostrovský, R., Toth, D. 2011. Pollen characteristics in Diospyros lotus L. Проблемы современной палинологии: Материалы XIII Российской палинологической конференции. т. 1. Сыктывкар: ИГ Коми НЦ УрО РАН, с. 26-29.

Grygorieva, O., Brindza, J., Ostrolucká, M.G., Ostrovský, R., Klymenko, S., Nôžková, J., Tóth, D. 2010. Pollen characteristics in some persimmon species (Diospyros spp.). Agriculture, vol. 56, no. 4, p. 121-130.

Grygorieva, O., Brindza, J., Vietoris, V., Kucelová, L., Tóth, D., Abrahamova, V., Hricová, M. 2011. Morphological and organoleptic fruit properties of various persimmon species (Diospyros spp.). Potravinarstvo Slovak Journal of Food Sciences, vol. 5, no. 3, p. 11-19. http://www.potravinarstvo.com/journal1/index.php/ potravinarstvo/article/view/150/pdf

Grygorieva, O., Nikolaieva, N., Brindza, J., Klymenko, S. 2015. Pollen and bee pollen features of sweet chestnut (Castanea sativa Mill.). Науковий вісник Начіонального університету біоресурсів i природокористування України. Серія Технологія виробництва $і$ переробки продукції тваринничтва, вип. 223, с. 35-40.

Hague, S.M. 1911. A morphological study of Diospyros virginiana. Botanical Gazette, vol. 52, p. 34-44. http:// www.jstor.org/stable/2467496

Jiang, Z.W., Wang, S.M., Zhang, Z.H., Huang, H.W. 2004. Pollen morphology of Actinidia and its systematic significance. Acta Phytotax Sin., vol. 42, p. 245.

Kodela, P.G. 2006. Pollen morphology of some rainforest taxa occuring in the Illawarra region of New South Wales, Australia. Telopae, vol. 11, no. 3, p. 346-389.

Martens, J. Fretz, T.A. 1980. Identification of eight crabapples by pollen surface sculpture. J. Amer. Soc. Hort. Sci., vol. 105, p. 257-263.

Mert, C. 2009. Pollen Morphology and Anatomy of Cornelian Cherry (Cornus mas L.) Cultivars. HortScience, vol. 44 no. 2, p. 519-522. http://hortsci.ashspublications.org/content/44/2/519.full.pdf+html

Miaja, M.L., Radicati, L., Porporato, M., Caramiello, R., Fossa, V., Vallania, R. 2000. Morpho-physiological observations on pollen of sour cherry (Prunus cerasus L.). Acta Hort., vol. 514, p. 311-318.

Nikolaieva, N.V., Grygorieva, O.V., Brindza, J., Garkava, K.G., Klymenko, S.V. 2014. Morphological features of pollen Corylus avellana L. and Castanea sativa Mill. as indicator of environmental changes. Плодоводство и ягодоводство России: сборник научных работ, т. 40, ч. 1, с. 232-238.

Rouhakhsh, H., Davarynejad, G., Abedi, B., Rahemi, M. 2014. Pollen Grain Morphological Characteristics of Ten Iranian Jujube (Ziziphus jujuba) Cultivars by Using Scanning Electron Microscopy. Advances in Environmental Biology, vol. 8, no. 5, p. 1333-1338. http://www.aensiweb.com/aeb.html

SAS. 2009. User's Guide Version 9. 2. SAS/STAT ${ }^{\circledR}$ SAS Institute Inc. Cary, NC, USA.

Sowunmi, M.A. 1995. Pollen of Nigerian Plants. Grana, vol. 34, p. 120-141.

Spongberg, S.A. 1979. Notes on Persimmons, Kakis, Date Plums, and Chapotes. Arnoldia, vol. 39, no. 5, p. 290-309. http://arnoldia.arboretum.harvard.edu/pdf/articles/1979-39-5-notes-on-persimmonskakis-date-plums-and-chapotes.pdf

Westwood, M.N., Challice, J.S. 1978. Morphology and surface topography of pollen and anthers of Pyrus species. J. Amer. Soc. Hort. Sci., vol. 103, p. 28-37.

Zohary, D. 2004. Unconscious selection and the evolution of domesticated plants. Economic Botany, vol. 58, p. 5-10.

Сравнительная эмбриология цветковых растений. 1983. Отв. ред. О.П. Камелина. Л. : Наука. 364 с. 